\title{
Fertilitas In Vitro dan In Vivo Spermatozoa Babi Landrace pada Pengencer Sitrat- Kuning Telur yang Disuplementasi Berbagai Level Fruktosa pada Penyimpanan Suhu $18^{\circ} \mathrm{C}$
}

\author{
In Vitro and In Vivo Fertility of Spermatozoa of Landrace Pig with Citrat- Yellow Egg Diluter \\ Supplemented on Various Levels of Fructose Stored in $18^{\circ}$ C Temperature
}

\author{
D. J. Djawapatty, H. L. L. Belli, dan T. M. Hine \\ Program Studi Peternakan Universitas Nusa Cendana \\ J1. Adisucipto, Kupang, Nusa Tenggara Timur 85001 \\ Email: david djawapatty@yahoo.co.id
}

\begin{abstract}
The goal of the first research was to find the best level of the used of the fructose into citrate of egg yolk (S-KT) on the presentage of the motility, viability, abnormality and the whole of the plasma membrane liquid semen of pig Landrace kept in $18^{\circ} \mathrm{C}$ degree and to be evaluation in six (6) hours. The research design for this stage include five treatments and four (4) replications. They were citrate of egg yolk (S-KT) without fructose (P0), S-KT + fructose $2.5 \%(\mathrm{P} 1), \mathrm{S}-\mathrm{KT}+$ fructose $5 \%(\mathrm{P} 2), \mathrm{S}-\mathrm{KT}+$ fructose $7.5 \%(\mathrm{P} 3)$ and $\mathrm{S}-\mathrm{KT}+$ fructose $10 \%(\mathrm{P} 4)$. The result of the research show the quality of the fresh semen is better because the motility and viability for each spermatozoid is $83.75 \pm 4.79 \%$ and $92.70 \pm 0.14 \%$. In vitro stage for 24 hours into the S-KT liquid that suplement by fructose $5 \%(\mathrm{P} 2)$ showed the motility $(40.00 \pm 4.08 \%)$ and the viability $(54.10 \pm 4.35 \%)$ higher so there was a significant different $(\mathrm{P}<0.05)$ compared with another liquid material. The abnormality and the whole of plasma membrane spermatozoid to the fourth liquid didn't have any different $(\mathrm{P}>0.05)$. The second research showed the score presentage of pregnant (for animal) and $\mathrm{S} / \mathrm{C}$. The highest score percentage of pregnant in this research was P1 with the score was $80 \%$, the lowest in P0 and P3 was $60 \%$, and the lowest score $\mathrm{S} / \mathrm{C}$ was P1 with the score was $1.25 \%$ and the higher in $\mathrm{P} 0$ and $\mathrm{P} 2$ was $1.67 \%$. The conclusion for the research is the fruktose suplement $5 \%$ in citrate of egg yolk can be hold out of the motility and viability of spermatozoid for pig Landrace up to $40 \%$ during 24 hours observation in the pregnant score is $67.50 \%$.
\end{abstract}

Key words: Pig semen, citrate of egg yolk, motility, unnatural insemination, pregnant

\begin{abstract}
ABSTRAK
Tujuan penelitian tahap I adalah untuk menentukan level terbaik penggunaan fruktosa dalam pengencer SitratKuning Telur (S-KT) terhadap persentase motilitas, viabilitas, abnormalitas serta keutuhan membran plasma semen cair babi Landrace yang disimpan pada suhu $18^{\circ} \mathrm{C}$ dan dievaluasi setiap 6 jam. Rancangan penelitian pada tahap ini terdiri dari 5 perlakuan dan 4 ulangan yaitu sitrat-kuning telur (S-KT) tanpa Fruktosa (P0), S-KT + Fruktosa 2,5\% (P1), S-KT + Fruktosa 5\% (P2), S-KT + Fruktosa 7,5\% (P3) dan S-KT + Fruktosa 10\% (P4). Hasil penelitian menunjukkan bahwa kualitas semen segar cukup baik karena motilitas dan viabilitas spermatozoa masing-masing adalah $83,75 \pm 4,79 \%$ dan $92,70 \pm 0,14 \%$. Tahap in vitro selama 24 jam dalam pengencer S-KT yan g suplementasi fruktosa $5 \%$ (P2) menunjukkan motilitas $(40,00 \pm 4,08 \%)$ dan viabilitas $(54,10 \pm 4,35 \%)$ lebih tinggi sehingga menunjukan perbedaan nyata $(\mathrm{P}<0,05)$ dibandingkan dengan bahan pengencer lainnya. Abnormalitas dan keutuhan membran plasma spermatozoa dalam keempat pengencer tidak berbeda $(\mathrm{P}>0,05)$. Penelitian tahap II untuk mengetahui persentase angka kebuntingan dan $\mathrm{S} / \mathrm{C}$. Persentase tertinggi angka kebuntingan dalam penelitian ini adalah $\mathrm{P} 1$ dengan nilai $80 \%$, terendah pada $\mathrm{P} 0$ dan $\mathrm{P} 3$ yaitu $60 \%$. Sedangkan nilai $\mathrm{S} / \mathrm{C}$ terendah adalah $\mathrm{P} 1$ dengan nilai $1,25 \%$ dan tertinggi pada $\mathrm{P} 0$ dan $\mathrm{P} 3$ yaitu $1,67 \%$. Kesimpulan dari penelitian ini adalah suplementasi fruktosa $5 \%$ dalam pengencer sitrat-kuning telur mampu mempertahankan motilitas dan viabilitas spermatozoa babi landrace di atas $40 \%$ selama 24 jam pengamatan dengan angka kebuntingan adalah $67,50 \%$.
\end{abstract}

Kata kunci: Semen babi, sitrat-kuning telur, motilitas, inseminasi buatan, kebuntingan. 


\section{PENDAHULUAN}

Salah satu jenis babi unggul yang banyak dipelihara di Nusa Tenggara Timur (NTT) adalah babi Landrace. Jenis babi ini seringkali digunakan sebagai sumber bibit untuk perkawinan silang dengan babi-babi lokal maupun dengan babi-babi jenis unggul lainnya seperti duroc dan sebagainya. Salah satu metode perkawinan silang yang digunakan pada ternak babi adalah dengan mengaplikasikan teknologi inseminasi buatan (IB). Di NTT, pelaksanaan IB pada ternak babi umumnya menggunakan semen segar (tanpa pengenceran). Hal ini dapat dimengerti karena ternak babi menghasilkan semen yang cukup banyak sehingga secara praktis kegiatan pengenceran dianggap tidak efisien.

Walaupun demikian, anggapan seperti itu tidaklah sepenuhnya benar karena walaupun pengnceran semen pada ternak babi tidak seefisien pada ternak sapi, pengenceran juga dapat meningkatkan $3-5$ kali lipat jumlah betina yang diinseminasi dari setiap ejakulat semen babi. Selain itu, pengenceran juga dapat meningkatkan motilitas dan daya tahan hidup spermatozoa babi (Tamoes et al., 2014) dengan demikian memperpanjang daya guna semen tersebut.

Bahan pengencer spermatozoa yang baik harus mengandung unsur-unsur yang hampir sama dengan sifat fisik dan kimiawi sperma dan tidak bersifat toksik (racun) terhadap spermatozoa dan alat reproduksi betina (Ismaya, 2014). Sitrat dan kuning telur merupakan bahan-bahan yang sudah umum digunakan untuk mengencerkan semen sapi. Namun, kedua bahan ini masih jarang digunakan untuk mengencerkan semen babi. Sitrat merupakan penyangga yang mampu mempertahankan kestabilan pH pengencer, sehingga menguntungkan untuk memelihara kelangsungan hidup spermatozoa. Kuning telur umumnya ditambahkan ke dalam pengencer semen sebagai sumber energi dan lipoprotein yang dapat memberikan perlindungan terhadap spermatozoa selama proses preservasi (Nalley et al., 2011). Kuning telur juga mengandung lipoprotein dan lesitin yang bekerja mempertahankan dan melindungi selubung protein dari spermatozoa (Robert, 2006). Fruktosa dalam pengencer mempunyai fungsi sebagai sumber energi yang digunakan dalam metabolisme juga diketahui dapat mempertahankan tekanan osmose dalam pelarut serta perlindungan dalam membran sel (Azawi et al., 1993)

Menurut Mukminat et al., (2014), penambahan berbagai sumber karbohidrat seperti fruktosa, glukosa dan sukrosa pada larutan pengencer semen dapat mempertahankan motilitas sperma sapi Bali setelah dibekukan serta dapat memperpanjang daya simpan semen sapi tersebut. Penambahan 1,75\% fruktosa pada pengencer air kelapa menghasilkan motilitas sperma dalam semen domba Garut yang disimpan selama 12 jam sebesar 57,18 \% (Rasad dan Simanjuntak, 2009). Selain itu, penambahan fruktosa pada pengencer dengan konsentrasi $0,6 \%$ memberikan motilitas sebesar $46 \%$ dan $51,33 \%$ daya hidup spermatozoa kalkun yang disimpan pada suhu $4^{\circ} \mathrm{C}$ (Atmaja et al., 2014). 
Penambahan karbohidrat berupa laktosa 0,6 $\%$.

Berdasarkan berbagai temuan dari penelitian-penelitian tersebut diharapkan suplementasi fruktosa ke dalam pengencer sitrat-kuning telur dapat meningkatkan kualitas semen cair babi Landrace yang selanjutnya bermuara pada peningkatan angka kebuntingan pasca inseminasi pada babi betina.

\section{MATERI DAN METODE}

Semen yang digunakan dalam penelitian ini bersumber dari 3 ekor babi jantan Landrace berumur 2-3 Tahun dengan berat badan yang proporsional. Bahan pengencer semen yang digunakan dalam penelitian ini terdiri dari sitrat, kuning telur (S-KT) dan fruktosa, bahan pewarnaan spermatozoa (eosin-negrosin), aquabidestilata dan alkohol 70\%, Antibiotic (penisillin dan streptomisin) dan larutan Host Test. Alat-alat yang digunakan adalah satu set alat penampungan semen (tabung penampung semen, dummy sow), satu set alat timbagan bahan (timbangan, spatula, alluminium foil), Satu set alat pengencer semen (gelas piala, gelas ukur, pipet, kertas saring, pinset, kapas, spoit, baskom stainless, stirrer dan spin bar), satu set peralatan evaluasi semen (mikroskop, obyek glass dan cover glass, heating table, kertas $\mathrm{pH}$, hemacyometer, pipet, open doff, tabung berskala, centrifuge untuk menghitung konsentrasi dan conthing chamber lengkap dengan pipet eritrosit), Coolbox sebagai alat penyimpanan semen dengan suhu $18^{\circ} \mathrm{C}$ yang dikontrol dengan thermometer, kateter dan botol IB untuk kebutuhan inseminasi.

Penelitian dilakukan dalam dua tahap yaitu: tahap 1 dilaksanakan untuk menemukan level fruktosa terbaik dalam pengencer SKT yang mampu mempertahankan motilitas, viabilitas dan daya tahan hidup sperma babi Landrace. Metode penelitian yang digunakan adalah metode eksperimen dengan menggunakan Rancangan Acak Lengkap dengan lima perlakuan dan lima ulangan (penampungan) sehingga terbentuk 25 unit percobaan. Adapun kelima perlakuan tersebut adalah: P0 (kontrol): SKT tanpa fruktosa, P1: SKT + fruktosa 2,5\% P2: SKT + fruktosa $5 \%$, P3: SKT + fruktosa 7,5 \%, P4: SKT + fruktosa $10 \%$.

Penelitian tahap 2 bertujuan untuk mengkaji dan menganalisis angka kebuntingan babi betina yang diinseminasi dengan semen yang dipreservasi pengencer terbaik pada penelitian tahap 1 dengan lama penyimpanan yang berbeda dan perlakuan kontrol. Metode yang digunakan dalam penelitian ini adalah metode eksperimental, menggunakan Rancangan Acak Kelompok dengan empat perlakuan dan 10 ulangan sehingga terbentuk 40 unit percobaan. Adapun keempat perlakuan tersebut adalah: P0 (kontrol): IB dengan semen yang diencerkan SKT, P1: IB dengan semen yang diencerkan SKT+ fruktosa $5 \%$ yang dipreservasi selama 0 jam, P2: IB dengan semen yang diencerkan SKT+ fruktosa 5\% yang dipreservasi selama 12 jam, P3: IB dengan semen yang diencerkan SKT+ fruktosa $5 \%$ yang dipreservasi selama 24 jam. 


\section{Koleksi dan Evaluasi Semen Segar}

Peroses penampungan semen dilakukan dengan metode pemijatan (massage/gloves hand method) pada korpus penis. Semen yang diperoleh dilakukan evaluasi secara makroskopis dan mikroskopis. Evaluasi makroskopis meliputi: volume, warna, $\mathrm{pH}$, dan konsistensi semen; sedangkan evaluasi mikroskopis meliputi motilitas (gerakan individu), viabilitas, konsentrasi, dan abnormalitas semen.

\section{Pengenceran Semen}

Semen yang berkualitas baik $(\geq$ $70 \%$ spermatozoa motil) dibagi menjadi lima bagian, dan masing-masing bagian diencerkan dengan salah perlakuan yang dirancang yaitu: P0 (kontrol): SKT tanpa fruktosa, P1: SKT + fruktosa 2,5\% P2: $\mathrm{SKT}+$ fruktosa $5 \%, \mathrm{P} 3: \mathrm{SKT}+$ fruktosa $7,5 \%, \mathrm{P} 4: \mathrm{SKT}+$ fruktosa $10 \%$.

\section{Penyimpanan dan Evaluasi Semen Cair}

Semen cair disimpan dalam cool box pada suhu $18^{0} \mathrm{C}$. Evaluasi kualitas semen cair dilakukan setiap enam jam yang meliputi: motilitas, viabilitas, abnormalitas, membran plasma utuh (MPU). Alat yang digunakan pada penyimpanan semen adalah es batu, styrofoam, thermometer.

\section{Variabel dan Analisis Data}

Variabel yang diamati dalam penelitian ini adalah motilitas, viabilitas, abnormalitas, membran plasma utuh (MPU), angka kebuntingan dan service per conception $(\mathrm{S} / \mathrm{C})$. Data tentang motilitas, viabilitas, abnormalitas, daya tahan hidup, MPU, dan services per conception dianalisis dengan Analysis of Variance (ANOVA), dan dilanjutkan dengan uji Duncan. Sedangkan angka kebuntingan dianalisis dengan uji Chi kuadrat $\left(\mathrm{X}^{2}\right)$. Software yang digunakan untuk mengolah data adalah SPSS 21 for windows dan MS office exell 2007.

\section{HASIL DAN PEMBAHASAN}

\section{Motilitas Spermatozoa}

Tabel yang disajikan dibawah ini dapat dilihat bahwa pengamatan hingga jam ke-24 penyimpanan, penurunan persentase motilitas spermatozoa pada perlakuan P0: $17 \%$ dengan nilai $28,75 \pm 8,54 \%, \mathrm{P} 1: 21 \%$ dengan nilai $25,00 \pm 4,08 \%$, P2: $7 \%$ dengan $40,00 \pm 4,08 \%, \quad$ P3: $20 \%$ dengan nilai $25,00 \pm 4,08 \%$, dan $\mathrm{P} 4: 21 \%$ dengan nilai $20,00 \pm 4,08 \%$.

Hasil penelitian lebih tinggi dari pada penelitian Dapawole et al. (2014) mengatakan bahwa pada suhu yang sama mampu mempertahankan motilitas spermatozoa $45.00 \pm 3.54 \%$ selama 12 jam pada jam ke-15 adalah $38.00 \pm 2.74$, namun lebih rendah dibandigkan dengan Tamoes et al. (2014) melaporkan bahwa persentase motilitas adalah $43.50 \pm 4.18$ selama 42 jam menggunakan bahan pengecer Zorlesco.

Uji lanjut Duncan terhadap motilitas spermatozoa pasca pengenceran yaitu pada pengamatan jam ke-0 bahwa tidak ada perbedaan nyata antar perlakuan $(\mathrm{P}>0,05)$, namun pengamatan jam ke-12 perlakuan $\mathrm{P} 2$ menunujukkan perbedaan nyata $(\mathrm{P}<0,05)$ terhadap perlakuan P0, P1, P3 dan P4. Pada pengamatan jam ke-18 menunjukan 
perbedaan tidak nyata $(\mathrm{P}>0,05)$ antar perlakuan. Pada pengamatan jam ke-24, perlakuan P2 menunjukan perbedaan nyata pada $(\mathrm{P}<0,05)$ terhadap perlakuan lainnya.
Rataan persentase motilitas semen cair babi Landrace dari masing-masing perlakuan dapat dilihat pada Tabel 1.

Tabel 1. Motilitas spermatozoa (\%) dalam pengencer sitrat kuning telur dengan level fruktosa yang berbeda

\begin{tabular}{cccccc}
\hline $\begin{array}{c}\text { Waktu } \\
\text { (jam) }\end{array}$ & P0 & P1 & P2 & P3 & P4 \\
\hline 0 & $81,25 \pm 2,50^{\mathrm{ab}}$ & $81,25 \pm 2,50^{\mathrm{ab}}$ & $82,50 \pm 2,89^{\mathrm{a}}$ & $77,50 \pm 5,00^{\mathrm{ab}}$ & $73,75 \pm 9,46^{\mathrm{b}}$ \\
6 & $61,25 \pm 2,50^{\mathrm{b}}$ & $63,75 \pm 4,79^{\mathrm{b}}$ & $73,75 \pm 2,50^{\mathrm{a}}$ & $63,75 \pm 4,79^{\mathrm{b}}$ & $61,25 \pm 2,50^{\mathrm{b}}$ \\
12 & $52,50 \pm 2,89^{\mathrm{b}}$ & $53,75 \pm 8,54^{\mathrm{b}}$ & $62,50 \pm 2,89^{\mathrm{a}}$ & $52,50 \pm 6,45^{\mathrm{b}}$ & $52,50 \pm 2,80^{\mathrm{b}}$ \\
18 & $45,00 \pm 0,00^{\mathrm{a}}$ & $46,25 \pm 8,54^{\mathrm{a}}$ & $47,50 \pm 6,45^{\mathrm{a}}$ & $45,00 \pm 9,13^{\mathrm{a}}$ & $41,25 \pm 8,54^{\mathrm{a}}$ \\
24 & $28,75 \pm 8,54^{\mathrm{b}}$ & $25,00 \pm 4,08^{\mathrm{bc}}$ & $40,00 \pm 4,08^{\mathrm{a}}$ & $25,00 \pm 4,08^{\mathrm{bc}}$ & $20,00 \pm 4,08^{\mathrm{bc}}$ \\
\hline
\end{tabular}

Superskrip abc yang berbeda pada baris yang sama menunjukan perbedaan nyata $(\mathrm{P}<0,05)$

Penambahan fruktosa cenderung lebih mempertahankan motilitas setelah preservasi, hal ini disebabkan karena fruktosa yang ditambahkan ke dalam pengencer yang digunakan merupakan jenis karbohidrat yang sama dengan karbohidrat yang terdapat di dalam plasma semen. Menurut Yildiz et al. (2000) spermatozoa sangat mudah memanfaatkan jenis gula fruktosa sebagai sumber energy. Garner dan Hafez (2000) menyatakan bahwa fruktosa di dalam pengencer semen dimanfaatkan oleh spermatozoa sebagai sumber energi baik dalam kondisi anaerob (pada saat penyimpanan), maupun kondisi aerob (pada saluran reproduksi betina). Perombakan fruktosa menjadi energi terjadi lebih cepat karena fruktosa dapat langsung diubah menjadi fruktosa 6-fosfat (6P), sedangkan jenis gula yang terdapat dalam pengencer zorlesco adalah glukosa.

Dari hasil penelitian motilitas spermatozoa menunjukkan bahwa spermatozoa dalam pengencer sitrat kuning telur dengan penambahan fruktosa pada level 5\% secara teknis layak dipakai untuk IB pada babi Landrace dengan menggunakan semen cair sampai penyimpanan 24 jam, karena memiliki persentase motilitas progresif di atas $40 \%$.

\section{Viabilitas Spermatozoa}

Persentase spermatozoa hidup lebih tinggi dari pada spermatozoa motil karena dari jumlah spermatozoa yang hidup belum tentu semuanya motil progresif (Kostaman dan Sutama 2006). Rataan persentase viabilitas dapat disajikan pada Tabel 2 berikut ini. 
Tabel 2. Viabilitas spermatozoa (\%) dalam pengencer sitrat kuning telur dengan level fruktosa yang berbeda

\begin{tabular}{cccccc}
\hline $\begin{array}{c}\text { Waktu } \\
\text { (jam) }\end{array}$ & P0 & P1 & P2 & P3 & P4 \\
\hline 0 & $82,06 \pm 6,06^{\mathrm{a}}$ & $87,02 \pm 3,91^{\mathrm{a}}$ & $88,68 \pm 2,57^{\mathrm{a}}$ & $90,50 \pm 3,08^{\mathrm{a}}$ & $65,80 \pm 38,55^{\mathrm{a}}$ \\
6 & $73,02 \pm 2,52^{\mathrm{b}}$ & $80,68 \pm 6,47^{\mathrm{ab}}$ & $84,05 \pm 2,79^{\mathrm{a}}$ & $80,65 \pm 8,59^{\mathrm{ab}}$ & $73,12 \pm 5,31^{\mathrm{b}}$ \\
12 & $58,48 \pm 5,79^{\mathrm{c}}$ & $72,23 \pm 7,14^{\mathrm{ab}}$ & $78,68 \pm 4,64^{\mathrm{a}}$ & $69,19 \pm 9,57^{\mathrm{ab}}$ & $64,22 \pm 4,92^{\mathrm{bc}}$ \\
18 & $48,03 \pm 3,45^{\mathrm{ab}}$ & $53,76 \pm 13,26^{\mathrm{ab}}$ & $62,76 \pm 5,75^{\mathrm{a}}$ & $61,59 \pm 7,54^{\mathrm{a}}$ & $42,70 \pm 15,26^{\mathrm{b}}$ \\
24 & $39,65 \pm 19,2^{\mathrm{b}}$ & $36,39 \pm 7,14^{\mathrm{b}}$ & $54,10 \pm 4,35^{\mathrm{a}}$ & $36,99 \pm 13,03^{\mathrm{b}}$ & $31,91 \pm 10,84^{\mathrm{b}}$ \\
\hline
\end{tabular}

Superskrip ${ }^{\text {abc }}$ yang berbeda pada baris yang sama menunjukan perbedaan nyata $(\mathrm{P}<0,05)$

Penurunan persentase viabilitas perlakuan berbeda-beda, namun penurunan tertinggi terjadi pada perlakuan P4 yaitu pada pengamatan jam ke-24 mencapai $31,91 \pm 10,84 \%$. Penuruna persentase viabilitas terendah terjadi pada perlakuan P2 dimana pada pengamatan jam ke-24 nilai persentase viabilitasnya adalah $54,10 \pm 4,35 \%$. Hasil penelitian ini masih berada pada kisaran penelitan Mukminat et al. (2014) mengatakan bahwa penambahan fruktosa pada pengencer skim kuning telur $2 \%$ dalam pembekuan semen sapi Bali dapat mempertahankan persentase viabilitas dengan nilai $55,59 \pm 2,53 \%$.

Penambahan fruktosa pada pengenceran semen dapat mempertahankan daya hidup spermatozoa, sebagai krioprotektan ekstraseluler fruktosa akan melindungi membran plasma sel sperma dari kerusakan secara mekanik yang mungkin terjadi saat proses kriopreservasi semen (Rizal, 2008). Disamping fruktosa sebagai kriprotektan ekstraseluler, fruktosa juga dapat berfungsi sebagai sumber energi cadangan bagi spermatozoa. Dimana dalam proses penyimpanan pada suhu dingin $\left(4^{\circ} \mathrm{C}\right)$, proses metabolisme spermatozoa akan tetap berlangsung meskipun terjadi penurunan metabolisme. Sehingga spermatozoa akan selalu membutuhkan energi untuk dapat bermetabolisme selama proses penyimpanan. Hal tersebut menyebabkan lama waktu penyimpanan berpengaruh terhadap motilitas dan daya hidup spermatozoa. Hasil uji lanjut Duncan terhadap persentase viabilitas dalam penelitan ini pada penyimpanan jam ke-24 menunjukan bahwa terdapat perbedaan yang nyata pada pada perlakuan P2 terhadap perlakuan lainnya.

\section{Abnormalitas Spermatozoa}

Pada Tabel 3, rataan persentase nilai abnormalitas spermatozoa pada semua perlakuan mengalami kenaikan pada akhir pengamatan. Abnormalitas spermatozoa terendah yang dihasilkan hingga pengamatan jam terakhir adalah perlakuan P2 yaitu sebesar 3,85 $\pm 0,78 \%$, sedangkan abnormalitas tertinggi dihasilkan oleh perlakuan P0 yaitu $4,49 \pm 0,47 \%$. 
Tabel 3. Abnormalitas spermatozoa (\%) dalam pengencer sitrat kuning telur dengan level fruktosa yang berbeda

\begin{tabular}{cccccc}
\hline $\begin{array}{c}\text { Waktu } \\
\text { (Jam) }\end{array}$ & $\mathrm{P} 0$ & $\mathrm{P} 1$ & $\mathrm{P} 2$ & $\mathrm{P} 3$ & $\mathrm{P} 4$ \\
\hline 0 & $2,87 \pm 0,52$ & $2,88 \pm 0,61$ & $3,51 \pm 1,39$ & $3,34 \pm 0,83$ & $3,30 \pm 1,32$ \\
6 & $3,12 \pm 0,60$ & $3,81 \pm 1,70$ & $4,08 \pm 1,33$ & $3,56 \pm 0,81$ & $3,73 \pm 1,26$ \\
12 & $3,83 \pm 0,41$ & $3,60 \pm 0,79$ & $3,40 \pm 0,75$ & $4,23 \pm 1,01$ & $4,19 \pm 1,00$ \\
18 & $4,26 \pm 0,59$ & $3,88 \pm 0,50$ & $3,45 \pm 0,74$ & $3,65 \pm 0,67$ & $4,28 \pm 0,79$ \\
24 & $4,49 \pm 0,47$ & $4,00 \pm 0,47$ & $3,85 \pm 0,78$ & $3,88 \pm 0,82$ & $3,89 \pm 0,24$ \\
\hline
\end{tabular}

Superskrip yang sama pada baris yang sama menunjukan perbedaan tidak nyata $(\mathrm{P}>0,05)$

Hasil penelitian menunjukkan terdapat perbedaan yang tidak nyata bahwa persentase abnormalitas spermatozoa mencapai $4,49 \pm 0,47 \%$ dan $3,89 \pm 0,24 \%$. Hasil ini masih baik karena menurut Foeh et al. (2015) melaporkan bahwa persentase abnormalitas spermatozoa babi adalah $11.1 \pm 4.0 \%$ dan $8.0 \pm 4.1 \%$. sedangkan menurut Johnson et al. (2000) persentase abnormalitas babi per ejakulat tidak boleh lebih dari $20 \%$.

Berdasarkan uji lanjut Duncan menunjukkan bahwa pada awal pengamatan hingga akhir pengamatan jam ke-24 $(\mathrm{P}>0,05)$ antar perlakuan. Hal itu disebabkan karena pemberian fruktosa pada level optimal mampu mengurangi peningkatan abnormalitas yang terjadi akibat peroksidasi lipid secara bersamaan.

Secara umum, abnormalitas pada spermatozoa dapat disebabkan oleh berbagai faktor antara lain genetik, stres, suhu lingkungan, penyakit dan bahkan perlakuan pada saat pembekuan semen (Arifiantini dan ferdian, 2006)

\section{Pengaruh Perlakuan terhadap MPU Spermatozoa}

Tabel 4. MPU spermatozoa (\%) dalam pengencer sitrat kuning telur dengan level fruktosa yang berbeda

\begin{tabular}{cccccc}
\hline $\begin{array}{c}\text { Waktu } \\
\text { (Jam) }\end{array}$ & \multicolumn{1}{c}{ P0 } & \multicolumn{1}{c}{ P1 } & P2 & P3 & P4 \\
\hline 0 & $87,40 \pm 6,40^{\mathrm{a}}$ & $87,94 \pm 3,78^{\mathrm{a}}$ & $87,92 \pm 4,04^{\mathrm{a}}$ & $89,64 \pm 2,22^{\mathrm{a}}$ & $82,86 \pm 7,57^{\mathrm{a}}$ \\
6 & $81,16 \pm 7,65^{\mathrm{a}}$ & $83,11 \pm 5,23^{\mathrm{a}}$ & $81,88 \pm 5,96^{\mathrm{a}}$ & $81,80 \pm 6.79^{\mathrm{a}}$ & $72.63 \pm 6.11^{\mathrm{a}}$ \\
12 & $69,32 \pm 11,12^{\mathrm{a}}$ & $70,88 \pm 8,95^{\mathrm{a}}$ & $70,02 \pm 13,07^{\mathrm{a}}$ & $70,16 \pm 5,24^{\mathrm{a}}$ & $63,89 \pm 3,30^{\mathrm{a}}$ \\
18 & $53,66 \pm 13,44^{\mathrm{a}}$ & $52,61 \pm 10,05^{\mathrm{a}}$ & $60,38 \pm 13,06^{\mathrm{a}}$ & $54,24 \pm 4,29^{\mathrm{a}}$ & $51,09 \pm 4,99^{\mathrm{a}}$ \\
24 & $30,59 \pm 9,10^{\mathrm{b}}$ & $39,89 \pm 19,68^{\mathrm{ab}}$ & $49,14 \pm 11,60^{\mathrm{a}}$ & $36,71 \pm 2,20^{\mathrm{b}}$ & $32,53 \pm 6,81^{\mathrm{b}}$ \\
\hline
\end{tabular}

Superskrip ${ }^{\mathrm{ab}}$ yang berbeda pada baris yang sama menunjukan perbedaan nyata $(\mathrm{P}<0,05)$

Hasil penelitian menunjukan bahwa penurunan persentase MPU pada jam dengan rataan persentase MPU masingmasing pada pengamatan jam terahir adalah
P0: $30,59 \pm 9,10, \quad \mathrm{P} 1: 39,89 \pm 19,68, \quad \mathrm{P} 2:$ 49,14 $\pm 11,60, \quad \mathrm{P} 3: 36,71 \pm 2,20$ dan $\mathrm{P} 4$ : $32,53 \pm 6,81$. 
Uji lanjut Duncan nilai MPU spermatozoa pasca pengenceeran hingga jam pengamatan jam ke-18 menunjukan perbedaan yang tidak nyata $(\mathrm{P}>0,05)$ antar perlakuan. Pada jam pengamatan ke-24 hasil uji lanjut Duncan pada MPU menunjukan perbedaan tidak nyata pada $(\mathrm{P}>0,05)$ antarperlakuan . Uji lanjut Duncan pada parameter ini tidak menunjukan perbedaan nyata antar perlakuan namun secara deskriptif mununjukkan bahwa pada perlakuan P2 mununjukkan nilai persentase MPU pada jam ke-24 dengan nilai tertinggi yaitu $49,14 \pm 11,60 \%$, dibadingkan dengan perlakuan lainnya.

Hasil penelitian ini berada pada kisaran penelitian Amin et al. (1999) yang melaporkan bahwa membran plasma utuh pada kerbau lumpur yang diencerkan dengan plasma semen sapi adalah 78,71 \pm 3,77 .

Tingginya nilai integritas membran yang diperoleh pada perlakuan plasma semen babi disebabkan karena kandungan protein plasma semen babi lebih sehingga kemampuannya dalam melindungi membran plasma sperma lebih baik. Dengan demikian hanya sedikit fosfolipid membran plasma sperma yang mengalami peroksidasi. Akibat dari peroksidasi akan terbentuk peroksid lipid, yang bereaksi dengan radikal bebas dan merangsang terjadinya reaksiotokatalitik, yang mengakibatkan rusaknya membran plasma (Sinha et al., 1996).

Menurut Colenbrander et al. (1992) kerusakan membran plasma pada bagian ekor juga menyebabkan terlepasnya enzim aspartat-aminotransferase

(AspaT) sehingga produksi ATP pada mitokondria akan terhenti dan mengakibatkan spermatozoa tidak dapat bergerak. Hal ini dipertegas oleh Siswanto (2006) yang menyatakan bahwa jika terjadi kerusakan pada mitokondria maka menyebabkan rantai oksida terputus, akibatnya mitokondria tidak bisa menjalankan fungsinya sebagai penghasil energi yang akan menggertak mikrotubuli akibat pergesekan ini spermatozoa dapat bergerak progresif

\section{Angka Kebuntingan}

Tabel 5. Persentase $\mathrm{S} / \mathrm{C}$ dan angka kebuntingan kegiatan IB dengan perlakuan semen cair P0 dan P2 5\% yang disimpan pada suhu $18^{\circ} \mathrm{C}$ selama $0-24$ jam penyimpanan sebelum Diinseminasi pada babi induk sebanyak 40 ekor

\begin{tabular}{ccccc}
\hline Perlakuan & $\begin{array}{c}\text { Jumlah } \\
\text { perlakuan }\end{array}$ & Bunting & $\begin{array}{c}\text { Angka kebuntingan } \\
(\%)\end{array}$ & S/C (\%) \\
\hline P0 & 10 & 6 & 60 & 1,67 \\
P1 & 10 & 8 & 80 & 1,25 \\
P2 & 10 & 7 & 70 & 1,43 \\
P3 & 10 & 6 & 60 & 1,67 \\
\hline
\end{tabular}

Keterangan :

$\mathrm{P0}=\mathrm{IB}$ menggunakan S-KT dengan lama penyimpanan 12 jam

$\mathrm{P} 1=\mathrm{IB}$ mengunakan $\mathrm{S}-\mathrm{KT}+$ Fruktosa $5 \%$ dengan lama penyimpanan 0 jam

$\mathrm{P} 2=\mathrm{IB}$ mengunakan S-KT + Fruktosa $5 \%$ dengan lama penyimpanan 12 jam

$\mathrm{P} 3=\mathrm{IB}$ mengunakan S-KT + Fruktosa $5 \%$ dengan lama penyimpanan 24 jam 
Persentase angka kebuntingan tertinggi dalam penelitian ini adalah P1 dengan nilai $80 \%$ dan terendah adalah $\mathrm{P} 0$ dan P3 yaitu $60 \%$. Hal ini diduga karna lama penyimpanan semen pada perlakuan P1 adalah 0 jam (pasca pengenceran langsung IB). Lama penyimpanan semen pada P0 dan P2 adalah 12 jam dan pada P3 adalah 24 jam. Rendahnya angka kebuntingan pada P0 dan P3 karena semakin lama daya preservasi maka akan menurunkan persentase motilitas dan viabilitas, dengan demikian fertilitas juga rendah. Namun nilai kegagalan dari hasil inseminasi dipengaruhi oleh tiga faktor yaitu kesuburan pejantan, kesuburan betina dan teknik inseminasi yang digunakan (Toelihere, 1993).

\section{Service per Conception (S/C)}

Service per conception (S/C) merupakan angka yang menunjukkan jumlah perkawinan yang dapat menghasilkan suatu kebuntingan, untuk memperoleh $\mathrm{S} / \mathrm{C}$ dari hasil penelitian didapatkan dengan pencatatan pelaksanaan IB pada peternak yang terdapat pada kartu IB.

Nilai S/C yang terendah terdapat pada $\mathrm{P} 1$ adalah 1,25 , sedangkan nilai $\mathrm{S} / \mathrm{C}$ yang tertinggi terdapat P0 dan P3 adalah 1,67. Apabila $\mathrm{S} / \mathrm{C}$ rendah, maka nilai kesuburan babi betina semakin tinggi dan apabila nilai $\mathrm{S} / \mathrm{C}$ tinggi, maka semakin rendah tingkat kesuburan babi betina tersebut. Nuryadi dan Wahjuningsih (2011) menyatakan bahwa kisaran normal nilai $\mathrm{S} / \mathrm{C}$ adalah 1,6-2,0
Nilai $\mathrm{S} / \mathrm{C}$ terendah dalam penelitian ini adalah perlakuan P1 karena kualitas semen yang digunakan dalam IB sangat baik dan hampir sama dengan kualitas semen segar yaitu persentase motilitas dan viabilitas masing-masing adalah $81,25 \pm 2,50 \% \quad$ dan $\quad 87,02 \pm 3,91 \%$. Sedangakan nilai $\mathrm{S} / \mathrm{C}$ tertinggi adalah $\mathrm{P} 0$ dan P3 seiringan menurunnya kualitas spermatozoa. Hasil ini didukung oleh Sihombing (2006) mengatakan bahwa keberhasilan inseminasi pada babi dipengaruhi oleh beberapa faktor diantaranya munculnya estrus setelah penyapihan, lama estrus, serta waktu antara muncul estrus dan ovulasi, serta kualitas sperma yang digunakan.

Hasil penelitian rata-rata nilai $\mathrm{S} / \mathrm{C}$ yaitu $1,50 \%$. Hasil ini sedikit lebih tinggi dari penelitian Sulaksono et al. (2010) melaporkan bahwa nilai $\mathrm{S} / \mathrm{C}$ yaitu pada kambing Boerawa adalah1,48 \%. Sulaksono et al. (2010) mengatakan bahwa tinggi rendahnya nilai $\mathrm{S} / \mathrm{C}$ dapat dipengaruhi oleh beberapa faktor antara lain keterampilan inseminator, waktu dalam melakukan inseminasi buatan dan pengetahuan peternak dalam mendeteksi birahi. Penyebab tingginya angka S/C umumnya dikarenakan : (1) peternak terlambat mendeteksi saat birahi atau terlambat melaporkan berahi kepada inseminator, (2) adanya kelainan pada alat reproduksi induk, (3) inseminator kurang terampil, (4) fasilitas pelayanan inseminasi yang terbatas, dan (5) kurang lancarnya transportasi (Iswoyo dan Widiyaningrum (2008). 


\section{KESIMPULAN}

Dari hasil analisis dan pembahasan maka dapat disimpulkan bahwa level terbaik fruktosa yang digunakan dalam pengencer sitrat-kuning telur adalah 5\%, karena mampu mempertahankan motilitas dan viabilitas selama 24 jam. Persentase angka kebuntingan tertinggi dan nilai $\mathrm{S} / \mathrm{C}$ terendah adalah semen cair yang diencerkan dengan sitrat-kuning telur + fruktosa $5 \%$ dengan lama penyimpanan 0 jam dengan nilai angka kebuntingan adalah $80 \%$ dan $\mathrm{S} / \mathrm{C} 1,25 \%$.

\section{DAFTAR PUSTAKA}

Amin, M. R., R.M. Toelihere, T. L. Yusuf, and P. Situmorang. 1999. Effects of Bovine Seminal Plasma Onfrozen Semen Quality of Swamp Buffaloes (Bubalus bubalis). Jurnal Ilmu Ternak dan Veteriner 4(3): 143-147.

Arifiantini, R.I. and F. Ferdian. 2006. Tinjauan aspek morfologi dan morfometri spermatozoa kerbau rawa (Bubalus bubalis) yang dikoleksi dengan teknik Mesase. J Vet. $7: 83$ 91.

Atmaja, W.K., M.K. Budiasa, dan W. Bebas. 2014. Penambahan Fruktosa Mempertahankan Motilitas dan Daya Hidup Spermatozoa Kalkun yang disimpan pada Suhu $4^{\circ} \mathrm{C}$. Indonesia Medicus Veterinus. 3 (4): 318-327.

Azawi, O.I, S.Y.A Al-Dahash, and F.T Juma. 1993. Effect of diferent diluent on Shami Goat Semen. Small Rums. Res. 9: 347-352.

Colenbrander, B., A.R. Fazeli, A. Van Buiten, J. Parlevliet, B.M. Gadella. 1992. Assesment of sperm cell membran integrity in the horse. Act Vet Scand. Supl. $88: 49-58$.

Foeh, N. D. F. K., R.I.I.S. Arifiantini, T.L. Yusuf. 2015. Kualitas Semen Beku Babi dalam Pengencer BTS dan MIII menggunakan Krioprotektan Dimethylacetamide dan Gliserol dengan Sodium Dedocyl Sulphate. Tesis. Sekolah Pascasarjana Institut Pertanian Bogor. Bogor.

Garner, D. L, E.S.S. Hafez. 2000. Spermatozoa and seminal plasma. In: E.S.E. Hafez, and B. Hafez, editor. Reproduction in farm Animals.7th Ed. USA: Williams \& Wilkins.

Ismaya. 2014. Bioteknologi Inseminasi Buatan pada Sapi dan Kerbau. Gadjah Mada University Press. Yogyakarta. ISBN: 979-420- 848-5.

Iswoyo dan P. Widiyaningrum. 2008. Performans Reproduksi Sapi Peranakan Simmental (Psm) Hasil Inseminasi Buatan di Kabupaten Sukoharjo Jawa Tengah. Jurnal Ilmiah Ilmu - Ilmu Peternakan. 11 (3): 125- 133 .

Johnson, L. A, J.G. Aalbers, C.M.T. Willems, J.H.M. Rademaker, C.E. Rexroad 1982. Use of boar spermatozoa for artificial 
insemination: bagian III Fecundity of boar spermatozoa stored in Beltsville liquid and Kiev extenders for three days at $18^{\circ} \mathrm{C}$. J Anim Sci 54 (1): $132-136$.

Sihombing, F. N. 2006. Pengaruh Sistem Pengawinan (Alami dan IB), Paritas dan Frekuensi Pengawinan terhadap Laju Kebuntingan Ternak Babi di Usaha Peternakan Babi PT. Adhi Farm, Solo. Skripsi. Program Studi Teknologi Produksi Ternak, Fakultas Peternakan, Institut Pertanian Bogor.

Kostaman, T. dan I. K. Sutama. 2006. Studi motilitas dan daya hidup spermatozoa kambing boer pada pengencer tris sitrat- fruktosa. J. Sain Vet. 24(1): 58-64.

Mukminat, A, S. Suharyati, Siswanto. 2014. Pengaruh penambahan Berbagai Sumber Karbohidratpada Pengencer Skim Kuning Telur terhadap Kualitas Semen Sapi Bali. Jurnal Ilmiah Peternakan Terpadu. 2 (2): 87-92.

Nalley, W.M.M. and R.I. Arifiantini, 2011. The live sperm $\%$ of local ram semen in Tris buffer with three di fferent egg-yolks. Anim Prod, 13: 39-44.

Nuryadi dan S. Wahjuningsih. 2011. Penampilan Reproduksi Sapi Peranakan Ongole dan Peranakan Limousin di Kabupaten Malang. J. Ternak Tropikal 12 (1): 76-81.
Rasad, S.D., L.C. Simanjuntak. 2009. The Effect of Fructose Addition in Semen Extender on Quality of Separation of Garut Ram Sperm in Several Storage Length. Animal Production. 11(3): 196- 201.

Rizal, M. 2008. Inseminasi Buatan pada Ternak. Jakarta: Rineka Cipta.

Sinha, M.P., A.K. Sinha, B.K. Singh, and R.L. Prasad.1996. The Effect of Glutatione on Motility, Enzyme Leakage and Fertility of Frozen Goat Semen. J. Anim. Reprod. Sci. 41: 237-243.

Siswanto. 2006. Kualitas semen dalam pengencer tris dan Natrium Sitrat dengan berbagai sumber karbohidrat dan level gliserol pada kriopreservasi semen Rusa Timor (Cervus timorensis) [Thesis]. Bogor (ID): Institut Pertanian Bogor.

Sulaksono, A., S. Suharyati, dan E. P. Santoso. 2010. Penampilan Reproduksi (Servise per Conception, Lama Bunting dan Selang beranak) Kambing Boerawa di Kecamatan Gedong Tataan dan Kecamatan Gisting. Fakultas Pertanian. Universitas Lampung. Lampung.

Tamoes, J.A., W.M. Nalley, T.M.Hine. 2014. Fertilitas spermatozoa babi Landrace dalam pengencer modifikasi zorlesco dengan susu kacang kedelai. J Sains Peternakan. 12 (1): 20-30. 
pISSN-1978-3000

eISSN-2528-7109

Toelihere, M.R. 1993. Inseminasi Buatan pada Ternak. Penerbit Angkasa. Bandung.

Yildiz, C., A. Kaya, M. Aksoy and T. Tekeli. 2000. Influence of Sugar
Supplementation of the Extender on Motility, Viability and Acrosomal Integrity of Dog Spermatozoa during Freezing. Theriogenology. 54 : 579585. 